\title{
Community-Based Approach in the Prevention and Management of Flood Disasters in Babessi Sub-Division (Ndop Plain, North West Cameroon)
}

\author{
Pamela Aka Tangan1, Primus Azinwi Tamfuh ${ }^{2 *}$, Alice Magha Mufur ${ }^{3}$, \\ Evine Laure Tanko Njiosseu ${ }^{4}$, Jules Nfor' ${ }^{1}$ Aminatou Fagny Mefire1, Dieudonné Bitom² \\ ${ }^{1}$ Department of Geology, Mining and Environmental Sciences, Faculty of Science, The University of Bamenda, Bambili, \\ Cameroon \\ ${ }^{2}$ Department of Soil Science, Faculty of Agronomy and Agricultural Sciences, University of Dschang, Dschang, \\ Cameroon \\ ${ }^{3}$ Department of Geology, Higher Teacher Training College, The University of Bamenda, Bambili, Cameroon \\ ${ }^{4}$ Department of Geology, Faculty of Science, The University of Dschang, Dschang, Cameroon \\ Email: *aprimus20@yahoo.co.uk
}

How to cite this paper: Aka Tangan, P., Azinwi Tamfuh, P., Magha Mufur, A., Tanko Njiosseu, E.L., Nfor, J., Mefire, A.F. and Bitom, D. (2018) Community-Based Approach in the Prevention and Management of Flood Disasters in Babessi Sub-Division (Ndop Plain, North West Cameroon). Journal of Geoscience and Environment Protection, 6, 211-228.

https://doi.org/10.4236/gep.2018.64013

Received: February 9, 2018

Accepted: April 9, 2018

Published: April 12, 2018

Copyright $\odot 2018$ by authors and Scientific Research Publishing Inc. This work is licensed under the Creative Commons Attribution International License (CC BY 4.0).

http://creativecommons.org/licenses/by/4.0/

\section{(c) (i) Open Access}

\begin{abstract}
Flood is a recurrent natural disaster that has caused enormous human and material damage in many places and continues to hit local committees at an alarming rate. The need to setup permanent committees to prevent and manage flood disasters by local communities is therefore indispensable. In rural areas, the creation of such a structure is always a welcome relief to flood victims but it is often marred by numerous management problems. This study aimed to analyze the community-based approach in the prevention and management of flood disasters in Babessi Subdivision (North West Cameroon), to identify the causes of flood disasters and the preventive strategies used by this local community. A total number of 300 questionnaires as well as structured interviews were used to collect data in the field and the data were analyzed by simple descriptive statistics. The main results revealed that the main cause of flood disasters is heavy and consistent rainfall. Also, poor refuse disposal and drainage system management contribute to floods. The identification of areas likely to be affected by floods and preventing the riparian population from constructing houses along these areas especially beside the main rivers are the flood preventive measures adopted by the local flood management committee. The flood victims are reluctant to relocate to the settlement site earmarked by the Government, meanwhile, the local flood committee do not have the legal tools to forcefully relocate them. The population of Babessi needs to be sensitized on the impending dangers of flood hazard and be encouraged to partici-
\end{abstract}


pate in implementing the adopted strategies to prevent and manage subsequent flood disasters.

\section{Keywords}

Disaster Management, Flood, Community-Based Approach, Ndop Plain, North West Cameroon

\section{Introduction}

Africa is a continent affected by a wide range of natural and human-induced hazards and disasters [1] [2] [3]. Events like floods, hurricanes, earthquakes, tsunamis, droughts, wildfires, pest plagues, and air and water pollution are very common [4]. Flood is one of the most devastating natural disasters with serious effects on the inhabitants and environment [2] [5] [6] [7]. Apart from direct impacts, for instance, on agricultural production and assets, floods are known to have serious direct and indirect social, psychological and other effects on victims. Such effects may be caused by the loss of human lives, the spread of faecal and vector-borne diseases, mental disorders and other forms of psychosocial traumas that often accompany floods or persist after such events occur [8] [9]. In developing countries, floods often result to thousands of deaths and epidemics, as well as destruction of infrastructure. From 1900 to 2006, floods in Africa killed nearly 20,000 people, affected nearly 40 million more, and caused damage estimated to about US\$4 billion [2] [10] [11]. High mortality rate from floods occurs in countries with poor, sparsely populated rural areas where disaster preparedness and early warning are almost inexistent. People in these areas have fewer possibilities for evacuation from flood prone areas and are more vulnerable to flood-related diseases. The causes of floods vary from natural to human-induced activities [12]. The rapid increase in flood frequency has been attributed to climate change, sudden heavy downpours, uncontrolled urbanization and deforestation [1] [13] [14] [15].

In Cameroon, urban areas have been identified as particularly vulnerable to flooding [5]. In 2001, severe floods hit the Limbe municipality causing the destruction of property and loss of lives [11]. In 2008, the Nkolbisson neighborhood suffered two severe floods [11]. Floods regularly affect the coastal towns of Cameroon like Limbe, Kribi, Tiko and Douala [4] [5]. In recent years, Yaoundé and Douala, major urban centers in Cameroon, were severely affected by floods at a frequency of 5 to 10 times per annum. In the Maga and Lagdo, rural areas in Northern Cameroon, frequency of occurrence ranged from 1 to 5 times per year [11]. In the Ndop-Plain (North West Cameroon), since the construction of the Bamendjin dam in 1975, floods have been frequent during each rainy season [16]. The 13 villages of the Upper Nun Valley have adopted various strategies to prevent and manage floods. At first, the intensities of floods were not alarming 
as they affected mostly springs, wells, toilets and farmlands without serious damage to property. In recent years, especially in 2012 and 2015, when the Babessi and Baba I floods respectively occurred, the magnitude was higher such that these communities were greatly affected [17]. Thus, the need for this local population to setup a permanent local flood management committee to prevent and manage flood disasters became indispensable. The creation of such a structure was a welcome relief to flood victims because Government machinery was often slow and characterized by numerous administrative bottle-necks. Nevertheless, the local community-based approach, although closer to the community to respond faster, is often marred by numerous problems like internal conflicts and mismanagement. The main objective of this work was to analyze the community-based approach in the prevention and management of flood disasters in Babessi Sub-Division (North West Cameroon), to identify the causes of flood disasters and the strategies used by the local community in preventing flood disasters.

The research hypotheses include:

Ho: community-based approach in prevention and management of flood disasters is well appreciated by the local population;

$\mathrm{H} 1$ : community-based approach in the prevention and management of flood disasters is not well appreciated by the local population;

Ho1: local flood disaster management committees increase stakeholder representation in decision making;

Ho2: local flood disaster management committees do not increase stakeholder representation in decision-making.

\section{Theoretical Groundwork}

A Social Science approach to flood disaster management is focused on understanding how this phenomenon is perceived in society: how people believe and feel about it [18]. This theoretical model endeavours to tackle both of these issues within an integrated context that draws upon Social Representations Theory (SRT) [19]. A social representation is a system of values, ideas and practices regarding a given social object, as well as the elaboration of that object by a group for the purpose of communicating and behaving. Accordingly, it provides a given group with a shared social "reality" and "common consciousness" about a particular social object [18]. SRT considers critically vital the information that circulates in society (for instance in the media, textbooks and literature) and the ideas in people's minds. SRT provides a framework for understanding and exploring how scientific knowledge diffuses in society and can become associated with intergroup power struggles [18] [19].

\section{Material and Methods}

\subsection{Study Site}

Babessi Sub-divisions is located in Ngoketunjia Division in the North West Re- 
gion of Cameroon, precisely in the Ndop Plain, between latitudes $6^{\circ} 50^{\prime} \mathrm{N}$ and $6^{\circ} 39^{\prime} \mathrm{N}$, and longitudes $10^{\circ} 23^{\prime} \mathrm{E}$ and $10^{\circ} 28^{\prime} \mathrm{E}$ (Figure 1). The total surface area is about $240 \mathrm{Km}^{2}$. The climate is the Cameroon type equatorial with two seasons: a rainy season of eight months (mid-March to mid-November) and a dry season of four months (mid-November to mid-March). The rainy season is characterized by torrential down pours ushered in by the monsoon winds, at times accompanied by destructive storms and hailstones. Mean annual rainfall is about $1700 \mathrm{~mm}$ and mean annual temperature is about $22^{\circ} \mathrm{C}$. The vegetation is mostly the Sudanian savannah composed of tall grasses and stunted trees here and there. This vegetation is strongly degraded by human activities like bushfires, intensive farming and overgrazing. The relief is undulating and made up mostly of hills and plains. The main hills include Etui, forghai in Babungo, Kaking and kangta hills at Bangolan. The lowland is a portion of the Ndop floodplain which is flooded during the rainy season. The Ndop Plain is drained by the Nun River and its numerous tributaries. The drainage pattern is of two types: radial and dendritic. Dominant soils are dark alluvial soils with a heavy clayey texture with kaolinite $(20 \%-45 \%)$, feldspars $(15 \%-40 \%)$, quartz (10\% - 20\%), illite (5\% $20 \%)$ and traces of smectite, goethite and gibbsite [21]. The alluvial soils (40\%) and colluviall soils (35\%) occur on the flooded plains, meanwhile hill slopes support lightly evolved soils (12\%), andosolic soils (8\%) and ferrallitic soils (5\%) [22]. The main rock types are plutonic rocks (20\% granite-gneiss), volcanic rocks ( $15 \%$ basalt, $4 \%$ trachyte, $5 \%$ rhyolite and $5 \%$ ignimbrite) [22]. Land use includes built up area (25\%) close to the Ndop town (49208 inhabitants) and four villages (Babungo, Babessi, Bangolan and Baba I), forest in the plain (10\%), subsistence farm area (25\%), plantation (20\%) and unused land (20\%) mainly slopes and alluvium (25\%).

The Ndop Plain is located between the Bamenda Mountains and the Oku Massif (part of the Cameroon volcanic line (Figure 2). Also enclosed within the

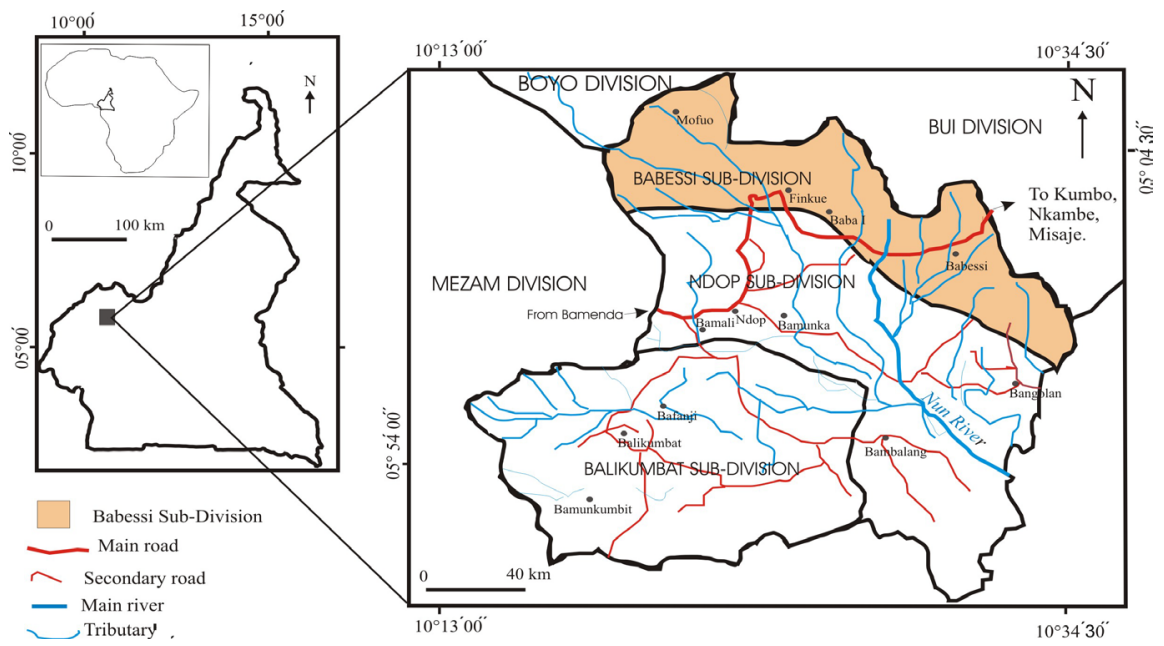

Figure 1. Location of Babessi Sub-Division in Ngoketundjia Division, Cameroon and Africa [20]. 


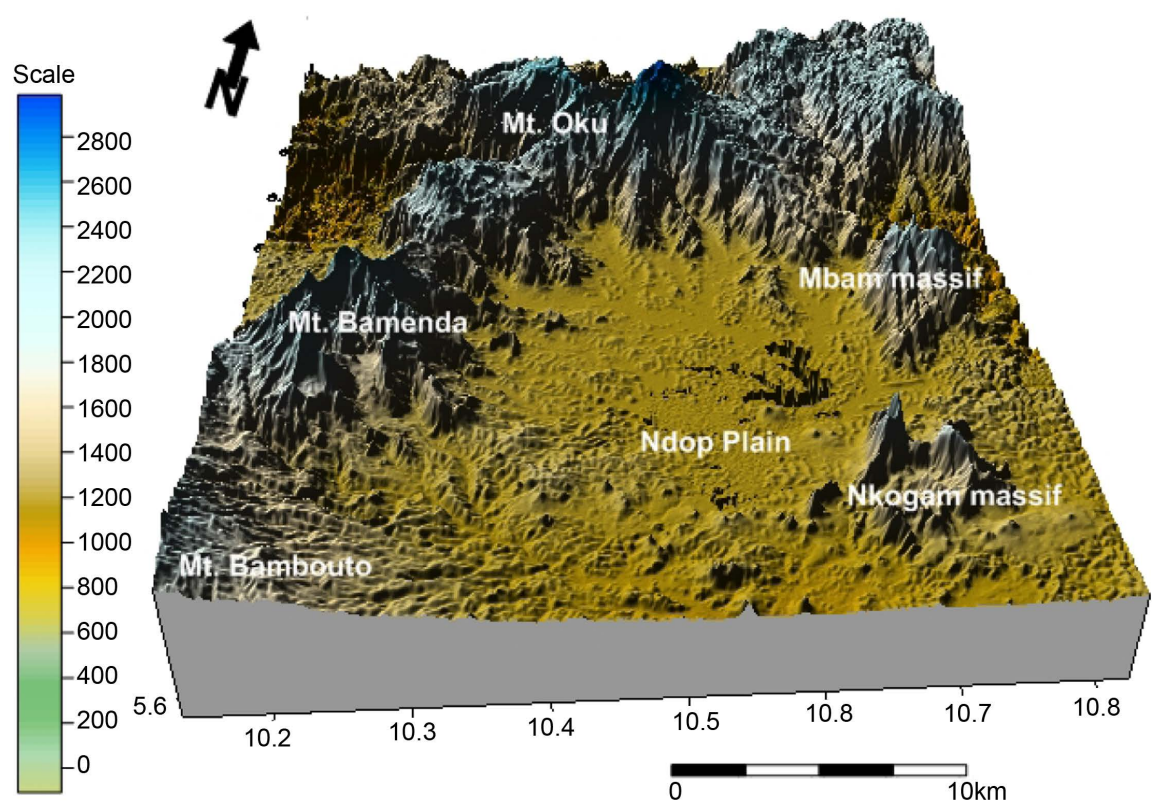

Figure 2. DEM of the Ndop Plain (STRM data, modified from [22]).

upper Nun watershed and bordered to the West by the Eastern escarpment (Sabga Mountains), this plain is characterized by colluvial and alluvial floodplains whose altitude ranges between 1150 and $1200 \mathrm{~m}$. These superficial deposits sorted from nearby highlands partly cover a Precambrian (600 - 500 Ma) granitic and gneissic basement overlain by a succession of Cenozoic felsic and mafic lavas of the Bamenda Mountains [23].

\subsection{Methodology}

\subsubsection{Data Collection}

This study was qualitative and made use of a blend of relevant historical inquiry and social science data gathering tools and presentation approaches. Data for this study was collected from primary and secondary sources from March to May 2016. Questionnaires were administered in Babessi Sub-Division in order to investigate the causes of the floods, prevention and management approaches of the disaster by the local community. Target resource persons were adult members or heads of household of flood victims and members of the communities who were eye witnesses of the flood disasters. A total of 300 questionnaires were distributed using purposive and convenience sampling techniques. Qualitative methods such as observations, key informant interviews and participatory discussions were also applied to complement the questionnaire. For convenience, the responses were grouped into different themes and presented in a narrative format. The literature for this study was derived from scholarly works on natural disasters in general and flood disasters in particular. Published and unpublished works on related themes of the study were consulted to collect information to help better analyze the approaches used in the prevention and management of 
flood disasters.

\subsubsection{Data Analysis}

The data were analyzed by simple descriptive statistics using SPSS (Version 16.0). The differences in the means between treatments were separated by Duncan's Multiple Range Test at 5\% significance level.

\section{Results}

\subsection{Age Group of Respondents}

Data analysis revealed that 140 (46.7\%) of respondents were between the ages of 15 and 29 years, while $50(16.67 \%)$ were between 30 and 49 years. One hundred (33.33\%) of the respondents were above 50 years and ten (3.33\%) of the respondent did not want to disclose their age for unknown reasons (Figure 3). There was a significant difference between the respondents based on age group $(P<$ $0.05)$.

\subsection{Gender, Level of Education and Status of Respondents}

Altogether, $140(46.7 \%)$ of the respondents were males while $160(53.3 \%)$ were females, with no significant difference $(p<0.05)$ between them (Figure 4$)$.

Figure 5 shows that $140(46.7 \%)$ of the respondents had the First School Leaving Certificate (FSLC). This constitutes the bulk of the respondents. Also, 50 (16.6\%) of the respondents were holders of the General Certificate of Education Ordinary Level (GCE OL), while 70 (23.3\%) were holders of the General Certificate of Education Advanced Level (GCE AL). Only 20 (6.7\%) had a Bachelor's Degree and 20 (6.7\%) respondents did not unfold their qualification. Although, the number of GCE AL holders where slightly higher than GCE OL holders, the general trend revealed that as the certificate becomes higher, the number of respondents holding it reduced significantly $(P<0.05)$.

The analysis of data revealed that $30 \%$ of the respondents were victims of the flood disaster while 70\% were non victims (Figure 6), thus portraying a

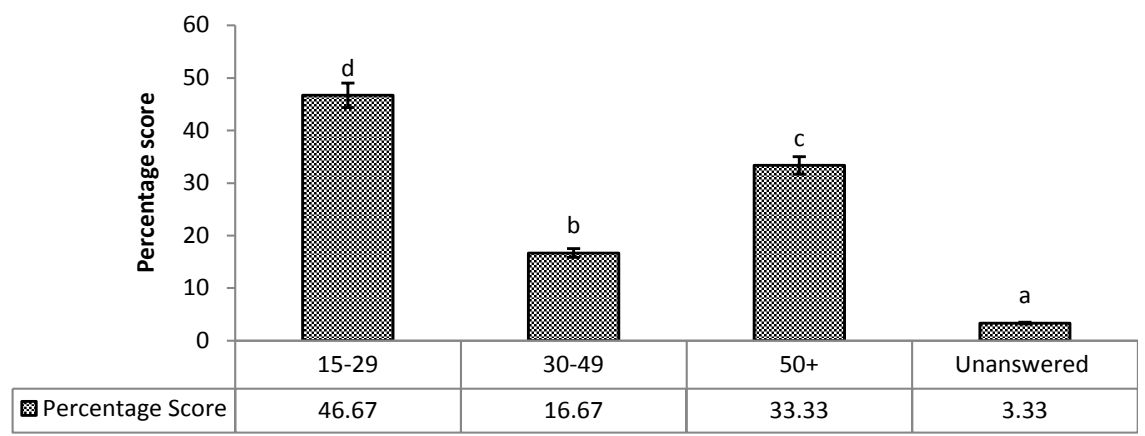

Age group

Figure 3. Identification of respondents by age group. Scores carrying the same letters are not significantly different $(\mathrm{p}<0.05)$. Bars represent standard deviation. 


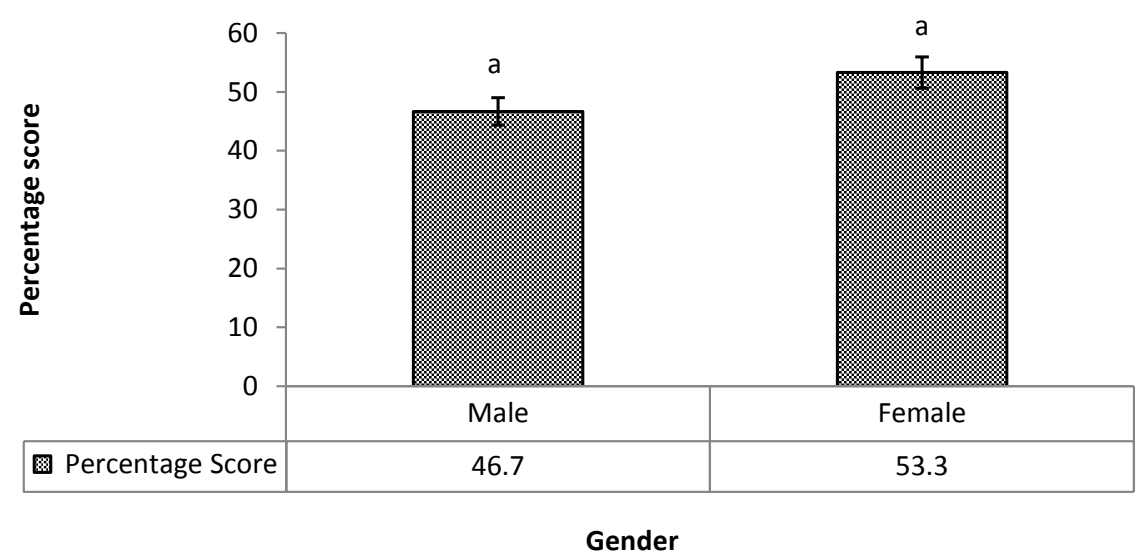

Figure 4. Identification of respondents by gender. The same letters (a) shows that both scores are not significantly different $(\mathrm{p}<0.05)$. Bars represent standard deviation.

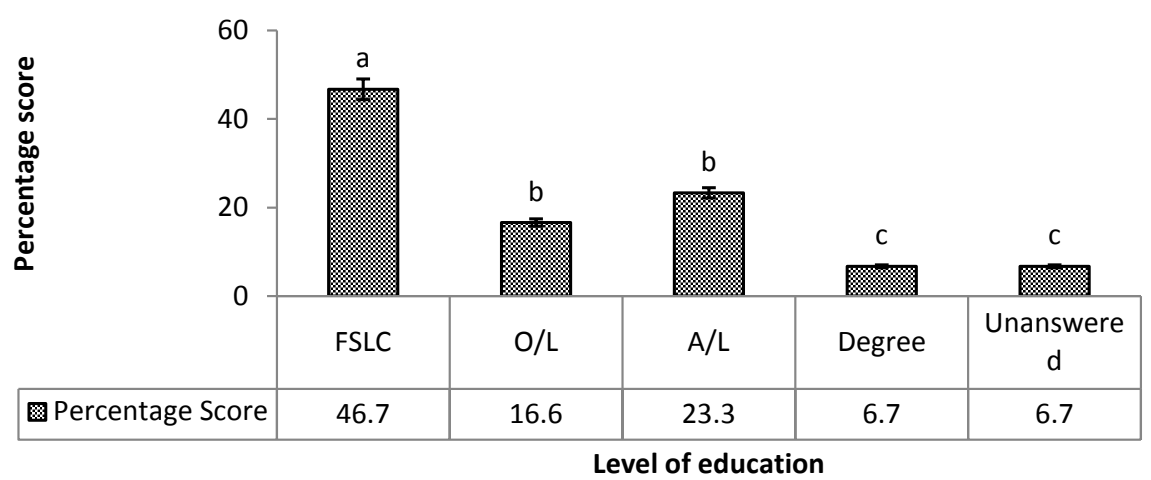

Figure 5. Educational level of respondents. Scores carrying the same letters are not significantly different $(\mathrm{p}<0.05)$. Bars represent standard deviation.

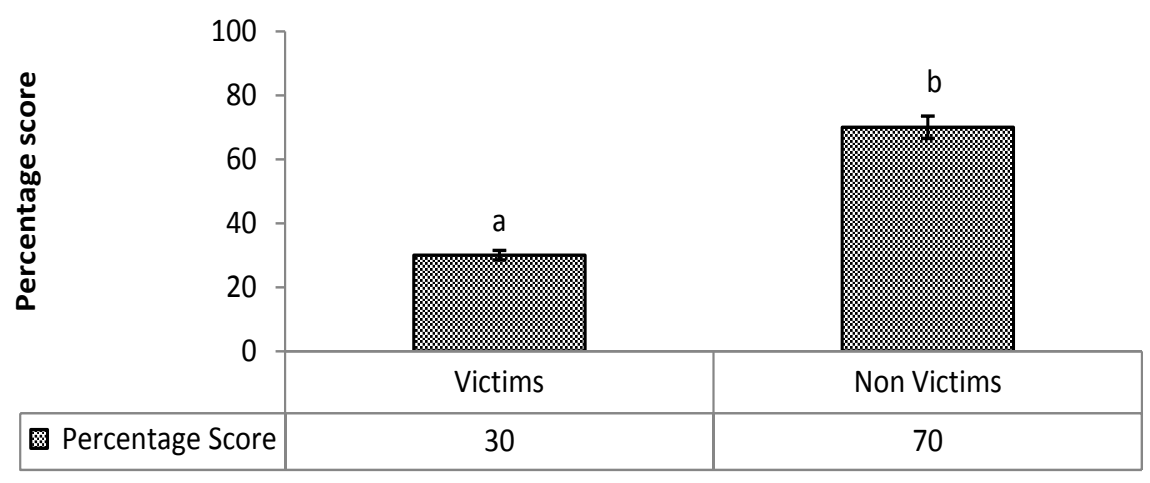

Respondent's status

Figure 6. Identification of respondents by status. The different letters ( $a$ and $b$ ) show that both scores are significantly different $(\mathrm{p}<0.05)$. Bars represent standard deviation.

significant difference $(P<0.05)$ between number of victims and non-victims.

\subsection{Causes of Floods in Babessi Sub-Division}

73.3\% of the respondents strongly agreed that the floods are caused by heavy and consistent rainfall due to seasonal changes (Figure 7). Also, 70\% of the 


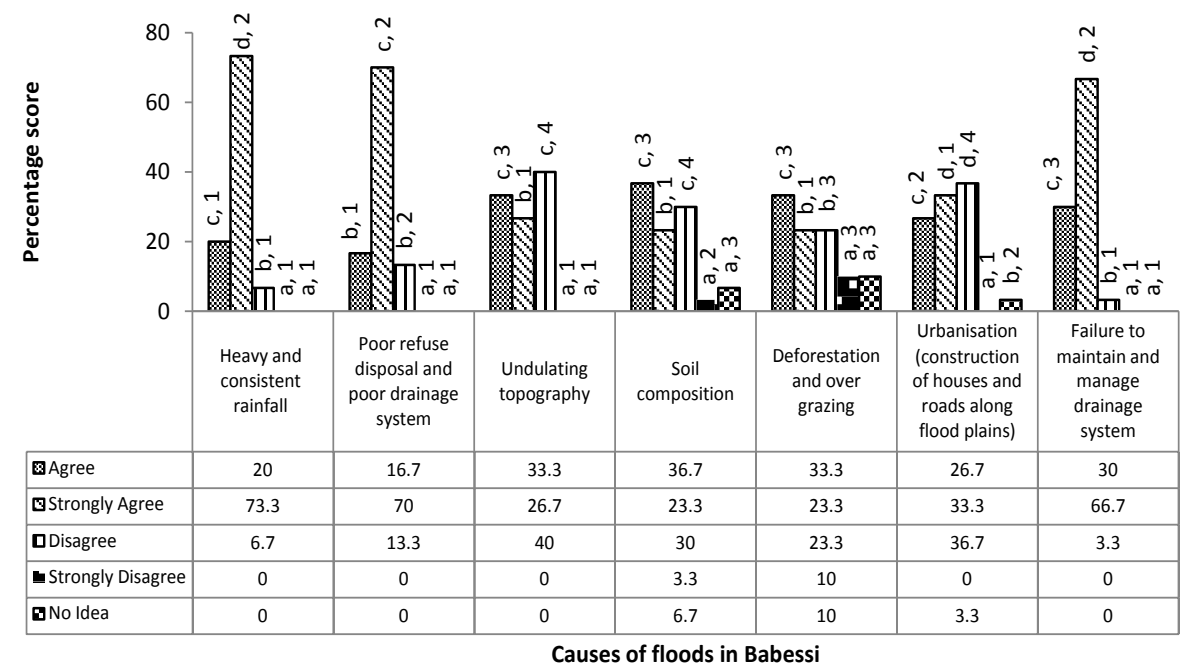

Figure 7. Causes of floods in Babessi. Scores represented by bars having different shades carrying the same letters are not significantly different; Scores represented by bars having similar shades carrying the same numbers are not significantly different $(\mathrm{p}<0.05)$. Bars represent standard deviation.

respondents agreed that poor refuse disposal and poor drainage systems account for the floods while $66.7 \%$ strongly agreed that the failure to maintain and manage drainage systems contributes to floods in Babessi Sub-Division.

The results equally demonstrated that $33.3 \%$ of the respondents agreed that deforestation and grazing are responsible for flooding in the area. On the other hand $40 \%$ and $36.7 \%$ disagreed that the undulating topography and urbanization, respectively, contribute to floods occurrence in Babessi.

\subsection{Local Committee Flood Disaster Prevention Approach in Ba- bessi}

Altogether, $50 \%$ of the respondents strongly agreed that people are prevented from constructing houses and living in the flood prone areas while $43.3 \%$ agreed that there is relocation of people from the flood prone areas (Figure 8). With heavy rains in the Ndop Plain and a dam further down, a flood is always inevitable. Also, $40 \%$ of the respondents agreed that the population is educated on soil and water conservation methods. $53.3 \%$ of the respondents disagreed to the fact that no farming was carried out along the flood prone areas. Also, $33.3 \%$ of the respondents strongly agreed that there was often forecasting and warning of the local population during the rainy season. In another dimension, $50 \%$ of respondents disagreed that dykes and dams have been constructed in Babessi in order to prevent floods disasters.

\subsection{Flood Disaster Management Approach in Babessi}

The flood management approaches are shown in Figure 9. Thus, $30 \%$ of 


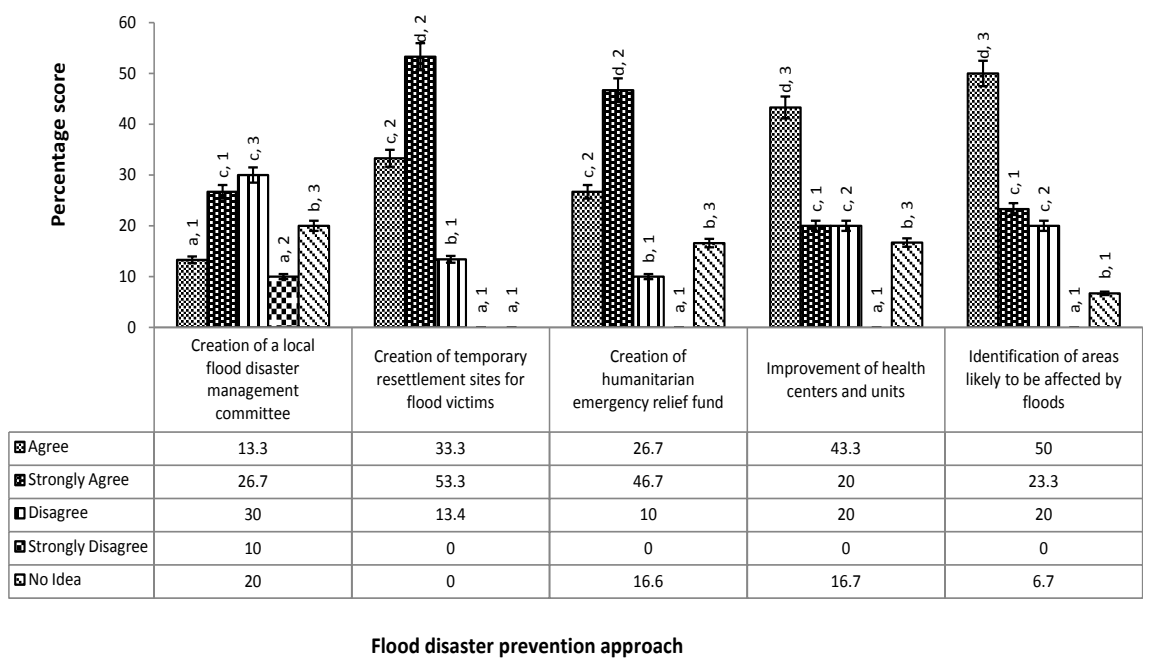

Figure 8. Local committee flood disaster prevention approach in Babessi Sub-Division. Scores represented by bars having different shades carrying the same letters are not significantly different; Scores represented by bars having similar shades carrying the same numbers are not significantly different $(\mathrm{p}<0.05)$. Bars represent standard deviation.

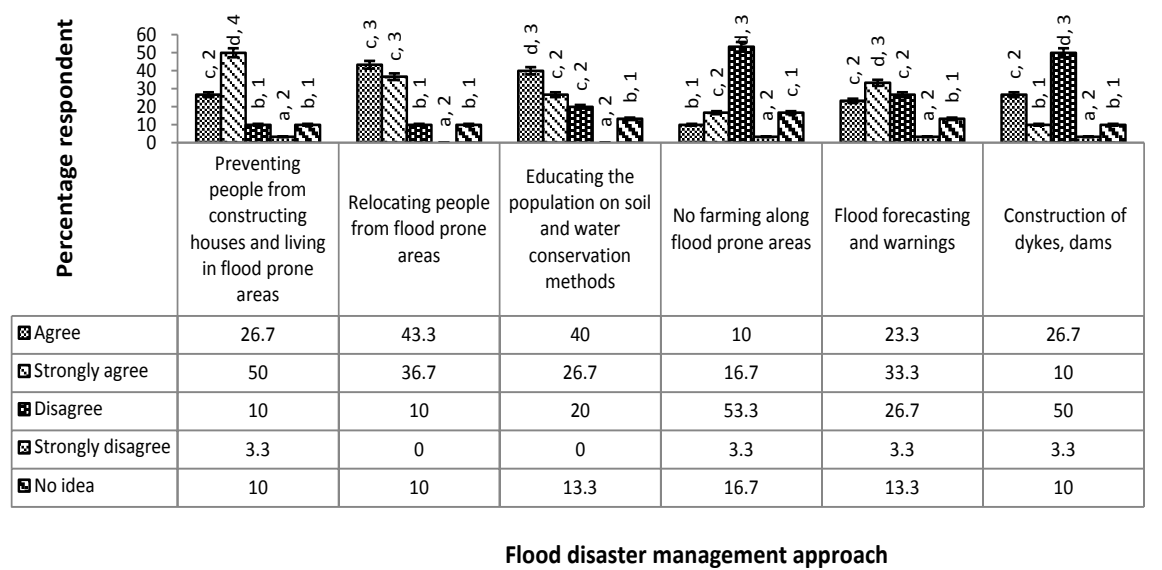

Figure 9. Various approaches to manage flood disasters in Babessi Sub-Division. Scores represented by bars having different shades carrying the same letters are not significantly different; Scores represented by bars having similar shades carrying the same numbers are not significantly different $(\mathrm{p}<0.05)$. Bars represent standard deviation.

respondents disagreed to the creation of a local flood disaster committee in the management of flood disasters. $53.3 \%$ of the respondents strongly agreed that a temporary resettlement site has been created for the relocation of flood victims, while $46.7 \%$ strongly agreed that a humanitarian emergency relief fund has been put in place to help flood victims. $43.3 \%$ respondents agreed that the Health Centre has been improved with medicine to spray the flood areas to avoid contamination of the local population during flood disasters. The results equally showed that $50 \%$ of the respondents agreed that there are areas which have been earmarked to be vulnerable to floods. These results confirmed the hypothesis 
that the community based approach in the prevention and management of flood disasters is well appreciated by the local population.

\subsection{Difficulties Encountered in the Prevention and Management of Floods}

More that $50 \%(53.3 \%)$ of respondents strongly agreed that the flood victims were reluctant to relocate to the land ( 40 hectares) set aside by the Government for the flood victims (Figure 10). The victims affirmed that they were reluctant to go there because they have to pay money before acquiring a piece of land. More so, the set amount for the victims is not adequate for resettlement and the construction of a new house as strongly agreed by $46.7 \%$ and agreed by $40 \%$ of respondents. The findings also indicated that $46.7 \%$ of the respondents affirmed that the local committee members mismanaged and misappropriated the money meant for flood victims. $40 \%$ of the respondents agreed that the victims did not follow the implementation approach to prevent and manage flood disasters. Also, $26.7 \%$ of respondents strongly agreed to this fact and $26.7 \%$ had no idea.

Concerning administrative influence, $36.7 \%$ of respondents agreed that there is Government influence in the management of flood disasters while $33.3 \%$ had no idea if Government intervenes in the affairs of the local flood committee or not.

\subsection{Effective Representation Rate of Local Population in Local Flood Committee}

The opinion of $63.3 \%$ of the respondents was that the local population was effectively represented in the local committee while $36.7 \%$ were not of this opinion (Figure 11).

\subsection{Category of People Represented in the Local Flood Committee}

Among the different categories of people in the locality, respondents believed

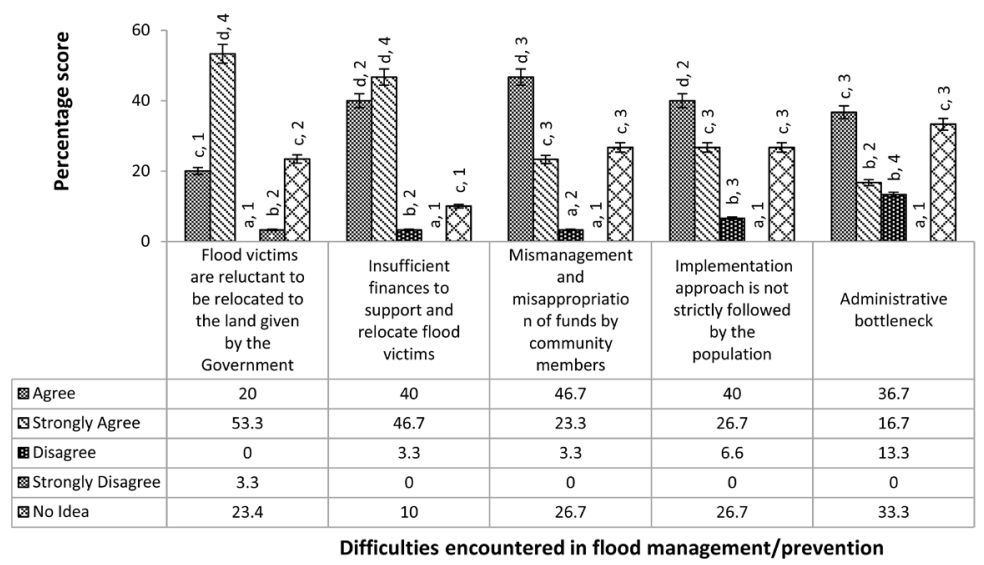

Figure 10. Difficulties encountered in the prevention and management of flood disasters in Babessi Sub-Division. Scores represented by bars having different shades carrying the same letters are not significantly different; Scores represented by bars having similar shades carrying the same numbers are not significantly different $(\mathrm{p}<0.05)$. 


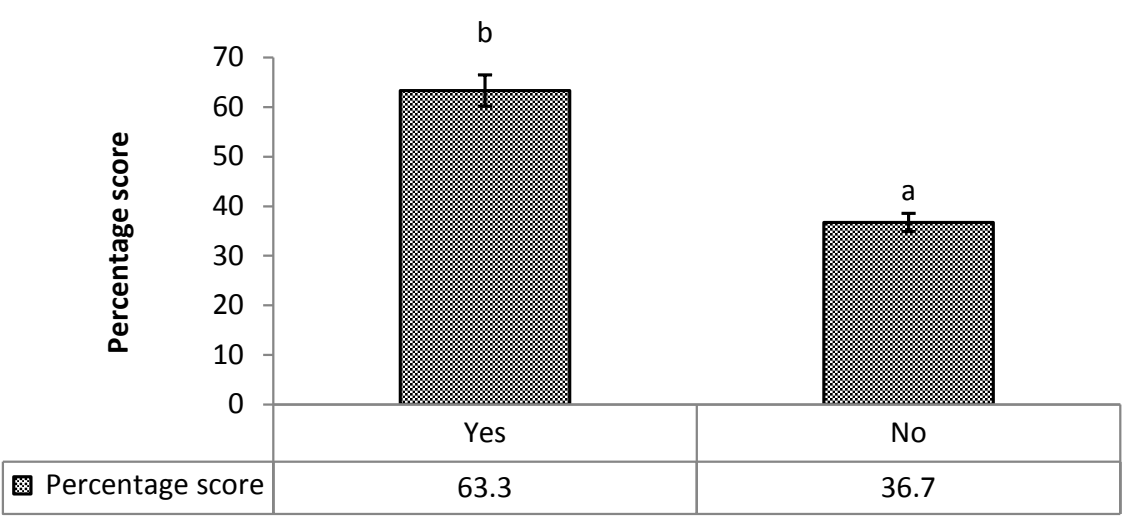

Response to effective representation

Figure 11. Effective representation of the local committee in flood management disasters in Babessi Sub-Division. The different letters ( $a$ and $b$ ) show that both scores are significantly different $(\mathrm{p}<0.05)$. Bars represent standard deviation.

that, apart from religious leaders with a significantly lower representation rate $(\mathrm{p}$ $<0.05)$ in the local flood committee, there is no significant difference in representation rate for the rest of the categories (Figure 12). Generally, all categories of people are equally represented in the local flood committee.

\subsection{Activities of the Local Flood Management Committee}

More than half of the respondents (53.4\%) agreed that the committee was doing a good job, $13.4 \%$ considered the committee as doing a fairly good job and $20 \%$ considered the job of the committee as bad and marred by favouritism, bias and nepotism in the distribution of the money allocated for flood victims (Figure 13).

\section{Discussion}

The Ndop Plain, located along the Cameroon Volcanic Line (CVL), is a volcano-tectonic plain, formed by a series of tectonic movements, volcanic eruptions and sedimentation phases. Seasonal floods occur with devastating effects [22]. Nevertheless, this plain attracts many people owing to its fertile alluvial soils resulting from erosion, transport and deposition of materials by streams and rivers as they flood seasonally [21]. Due to demographic pressure, there is the need to farm and inhabit new areas which are prone to floods (especially behind the Bamendjin Dam). Floods are the major hazard in the Ndop Plain due to its flat and extensive topography that make the easy evacuation of water difficult problem of space. Flood hazard may affect about 25\% of the Ndop Plain, along a north-south stripe [22].

The survey revealed that there was no significant difference between the gender of the respondents $(P<0.05)$. However, based on the education level of correspondents, almost $50 \%$ were holders of FSLC and as the certificate gets higher, the number of respondents reduces. This is true for most rural communities as the 


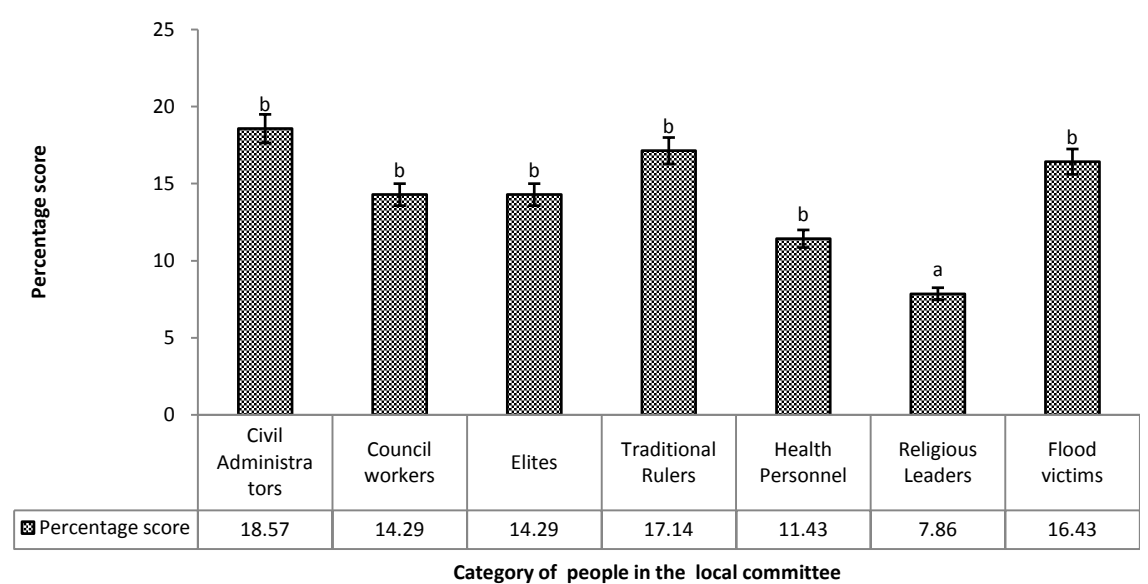

Figure 12. Category of people represented in the local flood management committee in Babessi Sub-Division. Scores carrying the same letters are not significantly different $(\mathrm{p}<$ 0.05). Bars represent standard deviation.

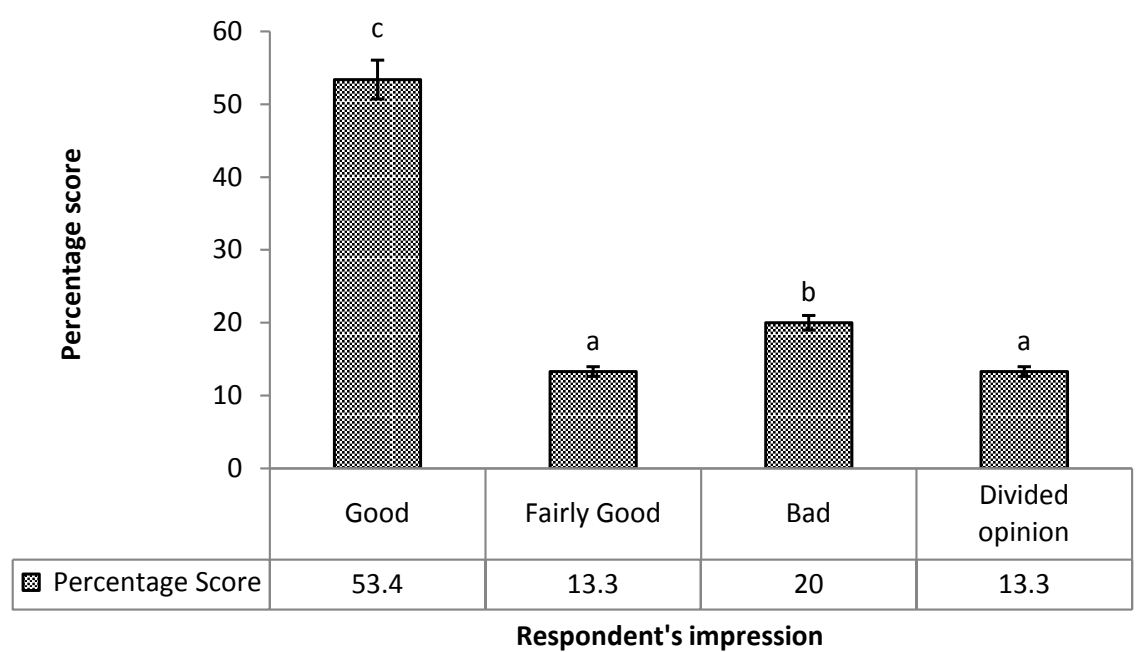

Figure 13. Respondent's impression about the activities of the local flood management committee in Babessi Sub-Division. Scores carrying the same letters are not significantly different $(\mathrm{p}<0.05)$. Bars represent standard deviation.

school drop-out rate increases with age and certificate [20]. Most of the respondents were youths aged between 15 and 29, while those between 30 and 49 years were the lowest in number. This distribution might simply be random, but note should be taken that the choice of respondents was based on target resource persons who were adult members or heads of households, flood victims and committee members who witnessed the flood disasters.

The analysis of the community-based approach in the prevention and management of flood disasters in Babessi revealed that there are many contributing causes to flooding in the area but the paramount cause is heavy and consistent rainfall that is attributed to seasonal changes. Previous scientific data by [22] has revealed that the causes of floods in the area include natural causes (siltation, 
peculiar geomorphology, the nature of soils, and rainfall) as well as anthropogenic causes (subsistence farming, plantation agriculture, the dam-backing effect of the Bamendjing Dam, and dumping of refuse into rivers). Perhaps, Babessi lies in the flat topography of the Ndop Plain, with a mean annual rainfall of 1700 $\mathrm{mm}$ and heavy clayey and impermeable soils. During heavy downpours, the Nun River often overflows its banks making the risk of flood disaster high in the area. Also, poor refuge disposal and poor management of the drainage system contributes to flooding in the area. These findings corroborate those of [17] [24] [25] [26], who affirmed that the major causes of floods are high rainfall and poor drainage system. Since the valleys are often very fertile, it is likely that earlier dwellers acquired land in these areas, which have turned out to be highly vulnerable to floods. Based on the assumption that a 'top-down approach' is not adequate for its implementation, development policy and emergency intervention should be coupled by a grass root or 'bottom-up' approach to enable communities concerned to function and contribute as a cohesive group. Theoretically, a community-based approach insists that people targeted for humanitarian assistance have the right to participate in making decisions that affect their lives as well as the right to information and transparency from those responsible to providing assistance; this will enable those who are affected to be better protected and their capacity to identify, develop and sustain solutions will be strengthened. Consequently, humanitarian resources will be used more efficiently.

Some measures adopted by the local flood committee in the prevention and management of flood disasters include the identification of flood-vulnerable zones and the prevention of people from constructing houses along these areas especially beside the main rivers and behind the dam. Also, creation of resettlement site and relocation of the victims are attempted solutions. This confirms the approach already reported by UN/ISDR/UNDP [3] [27] and Motoyoshi [28], where in Mozambique and Japan, the Government in collaboration with the local committees has taken appropriate measures in preventing and managing flood disasters. In Japan which is a highly vulnerable country to flood, the local committees are conscious and ready at any time to manage flood disaster if the precautions they have taken eventually fail.

The flood victims in Babessi are reluctant to relocate to the settlement site which has been earmarked by the Government (43.3\% strongly agreed and 36.7 agreed to this fact). The works of [17] also revealed that an overwhelming majority of the inhabitants of Babessi was reluctant either to self-relocate (66.7\%), or to do so as part of a Government policy (64.1\%) at local level. Previous research on disaster management in Cameroon suggests that such reluctance is largely due to the lack of trust in Government Institutions by local inhabitants in the management of natural disasters [29] [30]. On the other hand, it could also be influenced by factors such as land scarcity and social attachment to the community or to engagements in the moral community. Key informant interviews 
revealed that dead family members are a times buried inside the house in Babessi. Relocating will mean departing from love ones. Many victims do not seem prepared to be socially detached from the dead relatives through relocation. This agrees with APFM [31] that the impact of floods on communities is based on traditional backgrounds and features of communities. Another difficulty might have stemmed from the fact that money allocated to the victims was insufficient: 20 million francs CFA (about US $\$ 33,000$ ) worth of material assistance and 80 million francs CFA cash (about US $\$ 135,000$ ) to help rehabilitate the victims. Each victim was compensated by the Government with a maximum sum of 300,000 francs (about US\$500). The said amount was too small to effect any relocation of the flood victims. The local committee does not have the legal tool to forcefully relocate flood victims as some of them are indirectly affected.

Although $40 \%$ of the respondents agreed that the population is educated on soil and water conservation methods, $53.3 \%$ affirmed that farming was carried out along the flood prone areas. This is in line with Wotchoko et al. [22] who reported that $20 \%$ of the Ndop Plain is plantation land and that more people tend to farm near the main rivers. Also, most of the population holds a FSLC and might not properly master modern techniques of soil and water management. Generally people with higher years of education tend to have access to more sources and types of information. There is a likelihood that as educational level increases, there is higher chance to have better perception of environmental issues. These findings agree with a baseline survey among vulnerable communities in Bangladesh, where education shows a strong significant relationship with climate change knowledge [32]. Ndambiri et al. [33] and Badmos et al. [34] observed that the probability of more educated farmers to perceive climate change is higher than that of less educated farmers because higher education is likely to expose persons to more information on the environment and to understand complex issues. Thus, education affects scientific belief and can predict what and how people think.

The survey also showed that there is an administrative bottle-neck which does not allow the committee to carry out its activities effectively even without sufficient funds and available resources without the influence of the Government. This agrees with the findings of Ndille and Belle [35] that the strategy for managing disasters is plagued with too much bureaucratic bottle-neck, inadequate funds, and does not efficiently attain the goals of saving lives and reducing vulnerability.

The local population was effectively represented in the prevention and management of flood disasters. A cross-section of the representatives enabled to identify civil administrators, council workers, elites, traditional rulers, health personnel, religious leaders, and flood victims. This confirms the hypothesis that there is increase stakeholder representation in the local flood disaster committee and decision-making. The community can play a key role in the success of many non-structural measures of flood prevention and management such as awareness 
generation, popular knowledge valorisation, information dissemination, organising people, warning and evacuation. This could greatly help to reduce the cost of structural measures by the Government such as building and maintenance of local drainage systems [31]. The job which is done by the local committee is good though it is marred by favouritism and bias as some of the non-flood victims assumed to have benefited from government compensations. Numerous positive aspects of the present investigation, however, agree with the highlights of Jukrkorn et al. [36] on the Thailand megafloods in 2011 which emphasize the need for an integrated approach to flood risk management, combining local community-based approach and a national strategic policy in the preparation and reduction of vulnerability of the country. Building the capacity of less visible stakeholders (women, elders, remote people, minoriries) could held to better manage and prevent flood disasters. Also, the disparity in education, wealth, gender, age, culture or scientific/technical knowledge should be considered for the success of community activities [31].

\section{Conclusion}

The aim of this study was to analyze the community-based approach in the prevention and management of flood disasters in Babessi Sub-division (North West Cameroon). The main results revealed that the main cause of flood is heavy and consistent rainfall. Also, poor refuse disposal and management of the drainage system account for most floods in this area. The identification of areas likely to be affected by floods and preventing the riparian population from constructing houses along these areas especially beside the main rivers are the flood preventive measures which were adopted by the local flood committee. Also, flood victims are reluctant to relocate to the settlement site earmarked by the Government and the local flood committee does not have the legal tools to forcefully relocate them. The population of Babessi needs to be sensitized on the impending danger of any flood hazard and be encouraged to participate in implementing the adopted strategies to prevent and manage subsequent flood hazards. Efforts within flood risk management have to create solutions based on community ownership and consensus. By preparing and increasing community awareness and capacity of local Governmental authorities to handle flood situations has been recognized as a focal point for flood risk management.

\section{Acknowledgements}

Special thanks go to all respondents who eased this survey by kindly accepting to fill our questionnaires and to answer our questions. Special thanks also go to Nguedjio Christian Suh for his assistance in the realization of the maps.

\section{References}

[1] Ndenecho, E. and Fonsah, E. (2001) Wind Hazard: A Limitation to the Development of the Banana Industry in Tiko Plain, Cameroon. In: Lambi, C. and Eze, B., 
Eds., Readings in Geography: A Publication of the Research Group in Geography and Environmental Studies, University of Buea, Unique Printers, Bamenda, 191-206.

[2] Wisner, B., Blaikie, P., Cannon, T. and Davis, I. (2013) At Risk: Natural Hazards, Peoples Vulnerability and Disaster. $2^{\text {nd }}$ Edition, Routledge, New York, $124 \mathrm{p}$.

[3] UN/ISDR/UNDP (2004) Environmental Protection and Disaster Risk Reduction, A Community Leaders' Guide. UN/ISDR and UNDP, Geneva, Switzerland.

[4] Ndenecho, E.N. and Eze, B. (2004) Geomorphic and Anthropogenic Factors Influencing Landslides in the Bamenda Highlands (North West Province, Cameroon). Journal of Applied Social Sciences, 4, 15-26.

[5] Ayonghe, S.N., Mafany, G.T., Ntasin, E. and Samalang, P. (1999) Seismicity Activated Swarm of Landslides, Tension Cracks and Rock Fall in Bafaka, Cameroon. Natural Hazards, 19, 13-27. https://doi.org/10.1023/A:1008041205256

[6] Guedjeo, C.S., Kagou Dongmo, A., Ngapgue, F., Nkouathio, D.G., Zangmo Tefogoum, G., Gountié Dedzo, M. and Nono, A. (2012) Natural Hazards along the Bamenda Escarpment and Its Environs: The Case of Landslide, Rock Fall and Flood Risks (Cameroon Volcanic Line, North-West Region). Global Advanced Research Journal of Geology and Mining Research, 2, 15-26.

[7] Bronstert, A. (2003) Floods and Climate Change: Interactions and Impacts. Risk Analysis, 23, 545-557. https://doi.org/10.1111/1539-6924.00335

[8] Abuaku, B.K., Zhou, J., Li, X., Li, S., Li, X. and Liu, A. (2009) Morbidity and Mortality among Populations Suffering Floods in Hunan, China: The Role of Socioeconomic Status. Journal of Flood Risk Management, 2, 222-228.

https://doi.org/10.1111/j.1753-318X.2009.01037.x

[9] Bang, H.N. (2008) Social Vulnerability and Risk Perception to Natural Hazards in Cameroon Two Decades after the Lake Nyos Disaster: What Future Prospect for the Displaced Disaster Victims? Summer Academy for Social Vulnerability, 9-11 October 2008, United Nations University-Institute for Environmental and Human Security (UNU-EHS), Germany.

[10] Neira, Y., Nandi, A. and Galea, S. (2008) Post-Traumatic Stress Disorder Following Disasters: A Systematic Review. Psychological Medicine, 38, 467-480. https://doi.org/10.1017/S0033291707001353

[11] Tchindjang, M. (2012) Mapping of Natural Hazards in Cameroon. The University of Yaoundé 1, Yaoundé, Cameroon, 13 p.

[12] Nicholls, R.J. (2002) Analysis of Global Impacts of Sea-Level Rise: A Case Study of Flooding. Physics and Chemistry of the Earth, 27, 1455-1466. https://doi.org/10.1016/S1474-7065(02)00090-6

[13] Wilby, R.L., Beven, K.J. and Reynards, N.S. (2008) Climate Change and Fluvial Flood Risk in the UK: More of the Same? Hydrological Processes, 22, 2511-2523. https://doi.org/10.1002/hyp.6847

[14] Jonkman, S.N. and Kelman, I. (2005) An Analysis of the Causes and Circumstances of Flood Disaster Deaths. Disasters, 29, 75-97. https://doi.org/10.1111/j.0361-3666.2005.00275.x

[15] Fewtrell, L. and Kay, D. (2008) An Attempt to Quantify the Health Impacts of Flooding in the United Kingdom Using an Urban Case Study. Public Health, 122, 446-451. https://doi.org/10.1016/j.puhe.2007.09.010

[16] Mbih, R.A., Ndzeidze, S.K., Driever, S.L. and Bamboye, G.F. (2014) The Bamendjin Dam and Its Implications in the Upper Noun Valley, Northwest Cameroon. Journal 
of Sustainable Development, 7, 123-132. https://doi.org/10.5539/jsd.v7n6p123

[17] Balgah, R.A., Buchenrieder, G. and Mbue, I.N. (2015) When Nature Frowns: A Comprehensive Impact Assessment of the 2012 Babessi Floods on People's Livelihoods in Rural Cameroon. Jàmbá: Journal of Disaster Risk Studies, 7, 197-198. https://doi.org/10.4102/jamba.v7i1.197

[18] Aniah, P., Kaunza-Nu-Dem, M.K., Awinbugri Abindaw, B. and Millar, D. (2016) Characterizing and Explaining Smallholder Households' Views and Understanding of Climate Change in the Bongo District of Ghana. Earth Sciences, 5, 26-38. https://doi.org/10.11648/j.earth.20160502.12

[19] Moscovici, S. (1988) Notes towards a Description of Social Representations. European Journal of Social Psychology, 18, 211-250. https://doi.org/10.1002/ejsp.2420180303

[20] Neba, A. (1999) Modern Geography of the Republic of Cameroon. 3rd Edition, Neba Publishers, Bamenda, Cameroon.

[21] Yongue-Fouateu, R., Ndimukong, F., Njoya, A., Kunyukubundo, F. and Mbih, P.K. (2016) The Ndop Plain Clayey Materials (Bamenda Area-NW Cameroon): Mineralogical, Geochemical, Physical Characteristics and Properties of Their Fired Products. Journal of Asian Ceramic Societies, 4, 299-308. https://doi.org/10.1016/j.jascer.2016.05.008

[22] Wotchoko, P., Bardintzeff, J.-M., Itiga, Z., Nkouathio, D.G., Guedjeo, C.S., Ngnoupeck, G., Dongmo, A. and Wandji, P. (2016) Geohazards (Floods and Landslides) in the Ndop Plain, Cameroon Volcanic Line. Open Geosciences, 8, 429-449. https://doi.org/10.1515/geo-2016-0030

[23] Kamgang, P. (2003) Pétrologie et géochimie d'un secteur clé de la Ligne du Cameroun, les Monts Bamenda: Implications sur la genèse et l'évolution des magmas. Ph.D. Thesis, The University of Yaoundé 1, Yaoundé, Cameroon, 373p.

[24] Fogwe, Z.N. (2010) Mitigating and Managing Regional Geo-Environmental Hazards within a Decentralization Transition in Cameroon. Journal of Human Ecology, 30, 187-195. https://doi.org/10.1080/09709274.2010.11906288

[25] Nicholls, R.J. (2004) Coastal Flooding and Wetland Loss in the 21st Century: Changes under the SRES Climate and Socioeconomic Scenarios. Global Environmental Change, 14, 69-86. https://doi.org/10.1016/j.gloenvcha.2003.10.007

[26] Ingram, J.C., Franco, G., Rumbaitis-del Rio, C. and Khazai, B. (2006) Post-Disaster Recovery Dilemmas: Challenges in Balancing Short-Term and Long-Term Needs for Vulnerability Reduction. Environmental Science \& Policy, 9, 607-613. https://doi.org/10.1016/j.envsci.2006.07.006

[27] UN/ISDR/UNDP (2003) A Draft Framework to Guide and Monitor Disaster Risk Reduction. Geneva, Switzerland.

[28] Motoyoshi, T. (2006) Public Perception of Flood Risk and Community-Based Disaster Preparedness. Japanese Journal of Risk Analysis, 18, 121-134.

[29] Bang, H.N. (2013) Governance of Disaster Risk Reduction in Cameroon: The Need to Empower the Local Government. Jàmbá: Journal of Disaster Risk Studies, 5, 1-10. https://doi.org/10.4102/jamba.v5i2.77

[30] Ngwa, N.E. (1992) Responding to Unmet Food Needs of Displaced Persons or Refugees: A Case Study for New Approaches in Kousseri Town and Nyos Area of the Republic of Cameroon. GeoJournal, 27, 323-330.

[31] APFM-Association Programme on Flood Management (2017) Integrated Flood Management Tools Series-Community-Based Flood Management. The Mete- 
ological Organization, Geneva, Switzerland, 86 p.

[32] Kabir, M.I., Rahman, M.B., Smith, W., Lusha, M.A.F., Azim, S. and Milton, A.H. (2016) Knowledge and Perception about Climate Change and Human Health: Findings from a Baseline Survey among Vulnerable Communities in Bangladesh. BMC Public Health, 16, 266. https://doi.org/10.1186/s12889-016-2930-3

[33] Ndambiri, H.K., Mbogoh, S.G. and Ritho, C.N. (2013) An Evaluation of Farmers' Perceptions and Adaptation to the Effects of Climate Change in Kenya. International Journal of Food and Agricultural Economics, 1, 75-96.

[34] Badmos, B.K., Sawyerr, H.O., Awopeju, S.O., Salako, G.A., Abdulrasheed, A.A., et al. (2017) The Socioeconomic/Demographic Determinants of Public Perception about Climate Change in Ekiti State of Nigeria. Journal of Geography, Environment and Earth Science International, 9, 1-10.

https://doi.org/10.9734/JGEESI/2017/32400

[35] Ndille, R.N. and Belle, J.A. (2014) Managing the Limbe Floods: Considerations for Disaster Risk Reduction in Cameroon. International Journal of Disaster Risk Science, 5, 147-156. https://doi.org/10.1007/s13753-014-0019-0

[36] Jukrkorn, N., Sachdev, H. and Panya, O. (2014) Community-Based Flood Risk Management: Lessons Learned from the 2011 Flood in Central Thailand. WIT Transactions on Ecology and the Environment, 184, 75-86.

https://doi.org/10.2495/FRIAR140071 